\title{
CHANGING PATTERNS IN HOTEL ROOM DEMAND - CASE STUDY OF THE AQUATICUM DEBRECEN THERMAL AND WELLNESS HOTEL
}

\author{
G. Hevessy \\ University of Debrecen, Center of Agricultural Sciences and Engineering, Faculty of Applied Economics and \\ Rural Development \\ H-4032 Debrecen, Böszörményi Str. 138, Tel: +36-52-526-960, Fax: +36-52-526-964, \\ e-mail:hevessy@agr.unideb.hu
}

\begin{abstract}
Aquaticum Debrecen Thermal and Wellness Hotel is a very successful lodging property not only in Debrecen but also in the Northern Great Plain Region and in the Eastern part of Hungary and in point of fact in Hungary. In the past years Aquaticum Thermal and Wellness Hotel has been the leader in the region by revenue per available rooms (RevPAR). RevPAR indicates the overall performance of properties, accordingly it is the most commonly used statistical indicator in comparison to competitors in Hotel industry.

In the past years, demand for Hotel rooms has changed. This changing has several signs. For instance the occupancy rate, the rate of domestic and foreign guests, the nationality of foreign guests, the time between booking and travelling, and many other demand patterns have changed. During the last year, the changing has been accelerated by the global economic crisis.

Guests are waiting with their bookings hoping for better rates and last minute offers. The forecast of demand became much harder than ever before. These forecasts are basic ingredients of the revenue management systems, which systems are in use or will be in use by Hungarian Hotels. These systems are necessary to keep RevPAR at a higher level and to help Hotels to achieve better performance.
\end{abstract}

Key words: demand, Hotel, market, Aquaticum, revenue managemen

\section{Introduction}

In this chapter, I briefly introduce the Aquaticum Debrecen Thermal and Wellness Hotel and its role in the tourism of Debrecen and in the Northern Great Plain Region.

The four-star Aquaticum Debrecen Thermal and Wellness Hotel is situated in the first nature conservation area of Hungary, the leisure-time zone of Debrecen, in the heart of Great Forest of Debrecen. The Hotel is located in Aquaticum Medical and Bathing Centre, where thermal baths, indoor swimming pool, outdoor pools, the indoor Mediterranean Water Park, a medical department, a wellness island, a Thai Massage Centre, a Dental Centre and restaurants offering Hungarian specialties, provide complex services to the Hotel guests.

In the air-conditioned Hotel, 56 double rooms and 40 comfortable apartments await the guests. Each room features a balcony, bathroom with tub or shower, television, pay-tv, movie channel, WI-FI Internet connection, minibar, in room safe, hair-dryer, and bathrobes.

Aquaticum Mediterranean Water Park can be accessed directly from the Hotel via a glass-walled corridor. This direct connection is the most valuable facility of the Hotel. The abundant tropical flora and adventure elements of the special water centre conjure summer out of every single day of the year.
In the Mediterranean Water Park, a wave pool, children and baby pool, 12 slides, a climbing wall, slow-river corridors, water massage jets, water mushroom and neck showers, cave pools, pleasure paths and water choppers offer great entertainment. The Mediterranean Restaurant, Thai Massage Centre, as well as a Sauna Centre equipped with a Finnish sauna and steam chambers serve the recreation of the guests.

Nowadays the Hotel and the Water Park together is a paradise for families with little or bigger children. However, if we look back to the past we can see a different picture.

The Hotel was built in 1998 in order to provide services for guests who had rheumatic diseases. That time the market of medical tourism was large. The neighboring city Hajdúszoboszló had been world famous for its thermal water and known as the „Mecca of rheumatics”. The ingredients of the thermal water of Hajdúszoboszló and the thermal water of Debrecen are nearly the same. This fact and the success of the medical tourism in Hajdúszoboszló were the main drives of the idea of planning and building a Thermal Hotel in Debrecen in 1998 for treating guests who have rheumatic diseases. The largest part of the guests of Hajdúszoboszló was from Germany, especially from Eastern-Germany. In 1998, 40 apartments were built in the 96-room Aquaticum Thermal and Wellness Hotel in order to make the long stay of 
German guests more comfortable. These guests arrived for a 2 or 3 week-long cure. In the first five year, the average occupancy rate of the Hotel was 52\% and the management realized during those years that the potential of this market segment had been decreasing. A new target group had been set and the first indoor Mediterranean Water Park of Hungary opened in Debrecen in 2003. The success has exceeded the expectation.

\section{Materials and Methods}

Secondary data were obtained from the database of the Hungarian Central Statistical Office. Primary data were obtained by carrying out my own analyses and field research and from data collected in the Hotel. First, I had focused on primary markets of the Hotel and analyzed the changing of guest nights and guest arrivals from these markets.

Additionally, 9678 room reservations and price offer requests have been analyzed based on the time when the reservation or the request was received and based on the date of arrival of the guests. These inquiries were sent by individual guests from 01.01.2009 to 31.03.2010 through the website of the Hotel.

Furthermore, I have analyzed the booking curves of three-highlighted season in 2008, 2009, and 2010. These seasons are the New Year's Eve, the weekend of the Hungarian national holiday, 15th of March, and the Easter.

At last, I have analyzed the tendency of booking through the Hotel's website.

The analyses and comparisons were carried out by means of the software Microsoft Excel 2007.

\section{Results and discussion}

\subsection{Guest arrivals and market share in the past years}

As I mentioned before the nationality pattern of the guests has been changed. The main inbound markets are Rumania, Germany, Slovakia, and Ukraine. While the increasing number of Hungarian and Ukrainian guests has been refracted by the global economic crises, guest arrivals from Rumania and from Slovakia are increasing continuously (Fig. 1, Fig. 2).

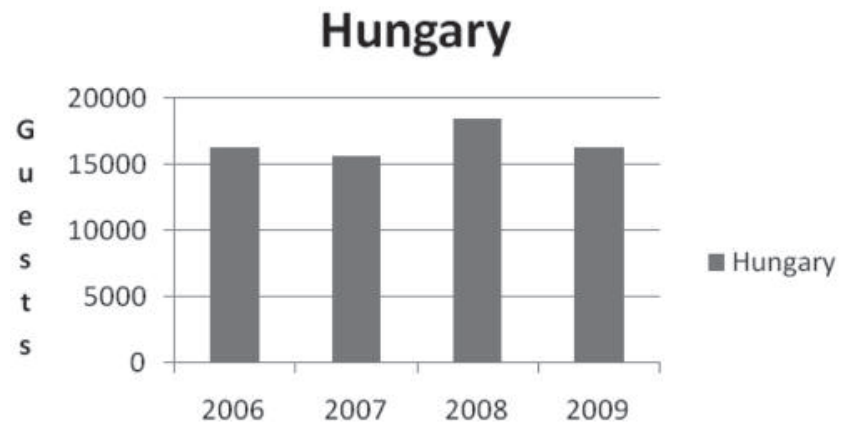

Figure 1. Number of guest arrivals from Hungary to the Aquaticum Hotel in the last four years.

(Source: Aquaticum Hotel database)

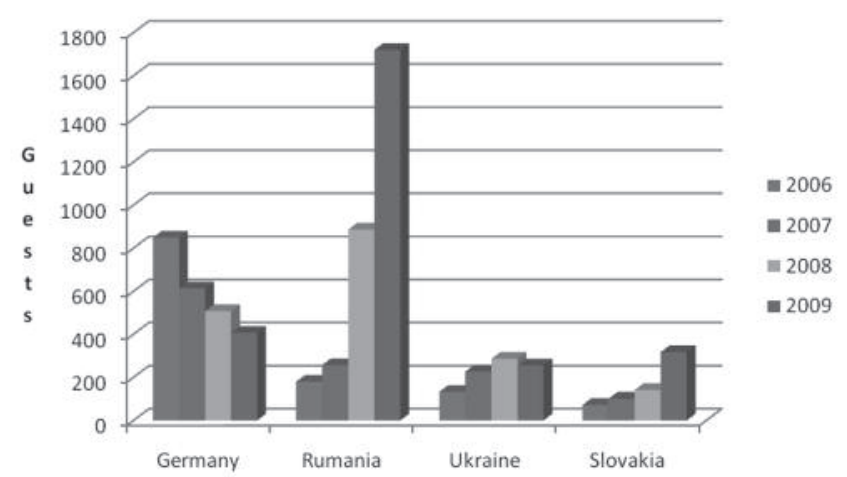

Figure 2. Number of guest arrivals from the main inbound markets of Aquaticum Hotel in the last four years.

(Source: Aquaticum Hotel database)

The number of guest nights shows almost the same picture (Tab. 1).

Table 1. Number of guest nights by key markets in the last four years

\begin{tabular}{|l|c|c|c|c|c|}
\hline & $\mathbf{2 0 0 6}$ & $\mathbf{2 0 0 7}$ & $\mathbf{2 0 0 8}$ & $\mathbf{2 0 0 9}$ & $\begin{array}{c}\text { Index } \\
\mathbf{( 2 0 0 9 /} \\
\mathbf{2 0 0 8})\end{array}$ \\
\hline Hungary & 41563 & 39753 & 44785 & 41139 & $91.9 \%$ \\
\hline Germany & 5105 & 3316 & 2895 & 2246 & $77.6 \%$ \\
\hline Rumania & 351 & 579 & 2289 & 4332 & $189.2 \%$ \\
\hline Ukraine & 528 & 742 & 1120 & 974 & $87.0 \%$ \\
\hline Slovakia & 138 & 232 & 384 & 857 & $223.2 \%$ \\
\hline
\end{tabular}

(Source: Aquaticum Hotel database)

The demand for Hotel rooms of Aquaticum from Rumania and from Slovakia doubled in the last two years. In 2009, Hungary became very cheap for Slovakian guests because of the HUF/EUR rate. HUF was weak and Slovakian guests got more HUF for their EUR. On the other hand, the negative impact of the global economic crises in Rumania was lower than in Hungary or in Ukraine. Demand from Germany decreased not only in Aquaticum Thermal and Wellness Hotel but also in other regions of Hungary. The competition among the countries on the German outbound market became bigger and bigger and it seems that Hungary has dropped behind.

In the last years, the ratio of the domestic and foreign guest nights has changed. While in 2007 the proportion of domestic guest nights was $82 \%$, in 2009 it was $76 \%$ (Fig. 3).

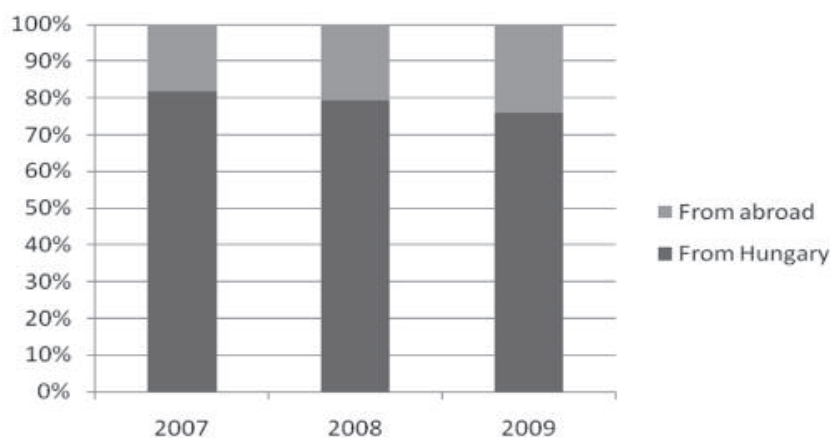

Figure 3. Ratio of guest nights.

(Source: Aquaticum Hotel database) 
Aquaticum Thermal and Wellness Hotel plays a key role in the tourism of Debrecen and in the tourism of the Northern Great Plain region as well. In spite of the global economic crises in 2009, the Hotel's market share of guest nights spent in the Hotels of Debrecen and in the Hotels of the region was greater than ever before (Tab. 2).

Table 2. Guest nights spent in Hotels and market share of the Aquaticum Hotel in the last four years.

\begin{tabular}{|l|c|c|c|c|c|}
\hline & Debrecen & $\begin{array}{c}\text { North Great } \\
\text { Plain Region }\end{array}$ & $\begin{array}{c}\text { Aquaticum } \\
\text { Hotel }\end{array}$ & $\begin{array}{c}\text { Market } \\
\text { share } \\
\text { (Debrecen) }\end{array}$ & $\begin{array}{c}\text { Market } \\
\text { share } \\
\text { (Region) }\end{array}$ \\
\hline 2006 & 318322 & 1237761 & 52348 & $\mathbf{1 6 . 4 \%}$ & $\mathbf{4 . 2 \%}$ \\
\hline 2007 & 304510 & 1252821 & 48602 & $\mathbf{1 6 . 0 \%}$ & $\mathbf{3 . 9 \%}$ \\
\hline 2008 & 288800 & 1243771 & 56525 & $\mathbf{1 9 . 6 \%}$ & $\mathbf{4 . 5 \%}$ \\
\hline 2009 & 232162 & 1081029 & 54159 & $\mathbf{2 3 . 3 \%}$ & $\mathbf{5 . 0 \%}$ \\
\hline
\end{tabular}

(Source: Hungarian Central Statistical Office, Aquaticum Hotel database)

\subsection{The time of making the reservations by the guests}

First, let us have a look at the time scale of receiving the inquiries (price offers and reservations) by the days of the week. Fig. 4 shows that the proportion of inquiries received on business days is much higher than those ones received on the weekends. On business days, a decreasing trend can be identified from Monday to Friday and it seems as if the guests were getting tired when the weekend is coming.

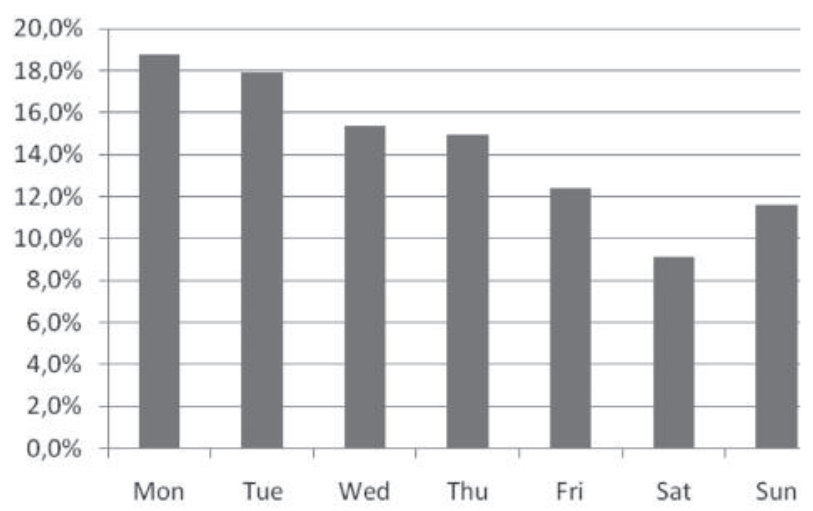

Figure 4. Ratio of received reservations and offer requests by day-of-week. (Source: Aquaticum Hotel database)

When we investigate the exact time of receiving inquiries on a day (Fig. 5) it shows that most of the inquiries have been sent during the business hours followed by a valley at 4-5 pm. (getting home) and there is another peak in the evening at $8 \mathrm{pm}$.

Aquaticum Thermal and Wellness Hotel is a great destination for families for a weekend. Weekends are high seasons in the Hotel. Fig. 6 proofs that most of the guests arrive on Friday. If we consider that the average length of stay is 2.6 days it is clear that, the busiest days in the Hotel are Fridays and Saturdays. Although the occupancy rate on weekends and on special Holidays (Easter, Christmas, etc,) was high enough both in 2009 and 2008, the demand for Hotel rooms has changed.

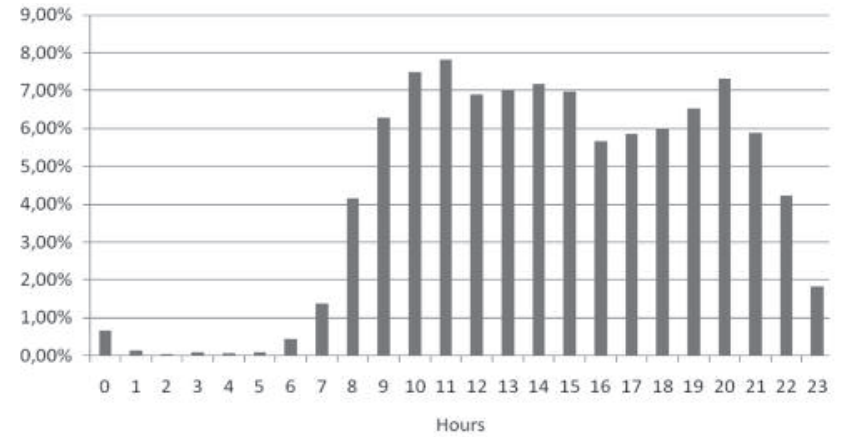

Figure 5. Ratio of received reservations and offer requests by hour-of-day. (Source: Aquaticum Hotel database)

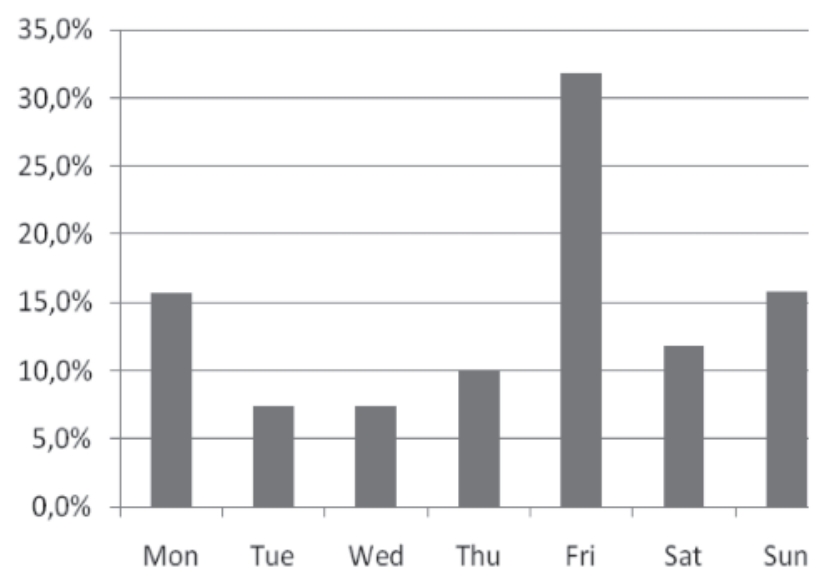

Figure 6. Ratio of guest arrivals by day-of-week.

(Source: Aquaticum Hotel database)

Demand forecasting plays a key role in the management operations of a Hotel. Every Hotel wants to maximize its revenue. Achieving this aim is unimaginable without demand forecasting, which is a very important ingredient of a revenue management system (Brewer-Marek, 2006). The fluctuations of demand made accurate forecasting very difficult and accordingly made many problems for revenue management systems (Sedat, 2007; Kimes, 2001). To manage the changing in demand for Hotel rooms is a great challenge for these systems.

\subsection{Analyzing the booking curves}

The evidence of the changing in demands can be discovered on the booking curves. The booking curve is a chart of occupancy rate of a given day, recorded at regular intervals. These intervals might be months before arrival, weeks before arrival, or days before arrival. The booking curve is a picture of the accumulation of bookings in the weeks leading up to an arrival date. Based on historical data, this curve provides information about general tendencies in booking behavior that can be very useful in forecasting future bookings.

Booking curves, like forecasts, can be created for specific days of the week, rate classes, or market segments or the data can be an aggregate of all reservations on hand.

If we have enough data to work with, we may want to create an average booking curve using averages of data sets. 
An average booking curve may provide stronger evidence of general trends than a booking curve based on just one data set, because it draws on a greater number of experiences (Kimes, 2010).

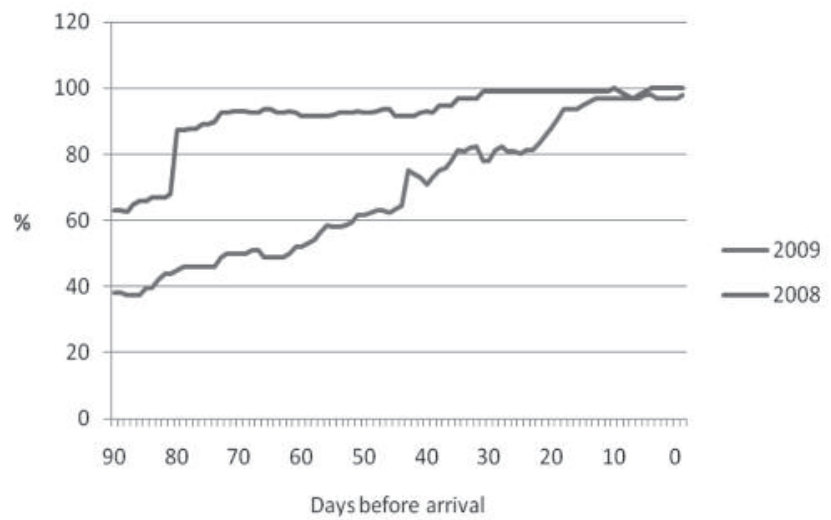

Figure 7. Booking curve of the New Year's Eve. Occupancy rate by the days before arrival.

(Source: Aquaticum Hotel database)

Examination of booking-pace data can lead to some surprising results. In 2009, 60 days before arrival the occupancy rate for the New Year's Eve was only 52\% while in 2008 the occupancy rate was $92 \% 60$ days before arrival. In 2009, a significant number of bookings are still taken, in the 40- to 15-day window prior to arrival. When the Hotel realized last year that they had much fewer reservations on hand, than they had a year before, they had to make an important decision. According to the literature Hotel rooms are generally price elastic because substitutions are available thanks to the high competition on the market and because the room rates make up a large portion of the consumer's total budget (Jagels-Ralston, 2007; Kimes, 2010; Seve, 2008). It means that a little reduction in prices may cause high increasing in demand. On first sight, the only thing that Aquaticum Hotel could do was to reduce price for the New Year's Eve in order to increase demand. However, the Hotel chose another way; they took the risk of not reducing their prices. Finally, success attended this strategy because the hotel had $98 \%$ occupancy rate for the New Year's Eve season in 2009.

The economic crises showed that price elasticity of demand for a Hotel room is not a simple question. A study made by the Hungarian Association of Hotels in March of 2010 pointed out that in spite of the decreasing rates the demand for Hotel rooms unfortunately did not increase dramatically (HAH, 2010). This study has given a proof of that the right decision, the right strategy is not to do panic, not to drop prices immediately. Aquaticum Debrecen Thermal and Wellness Hotel has applied the same room rates in 2010 than they applied in 2009 and 2008. As the graphs illustrate on the figures (Fig. 7, Fig. 8, Fig. 9) the Hotel can reach almost the same occupancy rates on the highlighted days than it could reach in the previous year.

In 2010, 11 days before arrival the occupancy rate for the 15 th of March was only $36 \%$ ! Finally, the Hotel could reach

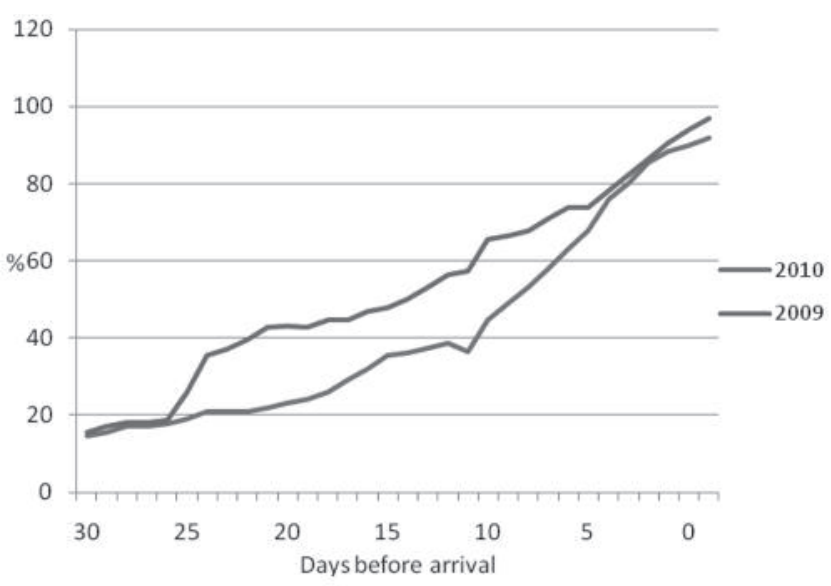

Figure 8. Booking curve of the National Holiday (15 th of March). Occupancy rate by the days before arrival.

(Source: Aquaticum Hotel database)

$92 \%$ ! Almost $61 \%$ of the reservations were received in the last 11 days. Such a great increasing in an 11 days term had never been registered before. The time interval between the date of booking and the date of travel decreased dramatically. This fact makes accurate forecasting nearly impossible.

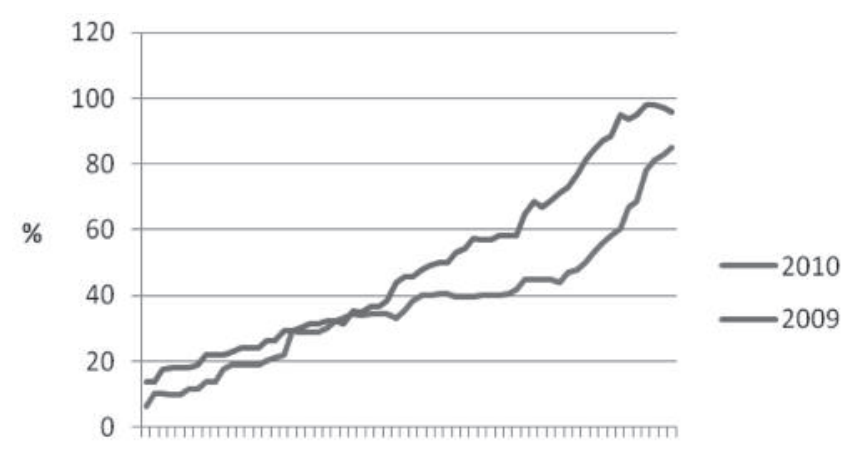

$6055504540353025201510 \quad 5 \quad 0$

Days before arrival

Figure 9. Booking curve of the Easter. Occupancy rate by the days before arrival.

(Source: Aquaticum Hotel database)

\subsection{Reservations received through the Hotel's website}

The Hotel received 3890 bookings through their website for 2009. These bookings were made by individuals, so the reservations of groups were not included. Every booking means different room nights. I have summarized the room nights of the bookings received through the website for the four quarters of the year 2009. These quarters had been denoted by Q1,Q2,Q3,Q4. Then I compared these sums to the total number of room nights booked by individuals and received in any kind of way (website, e-mail, phone, fax, etc.) (Fig. 10).

I analyzed the ratios instead of the natural numbers of room nights because the room nights vary month by month. 


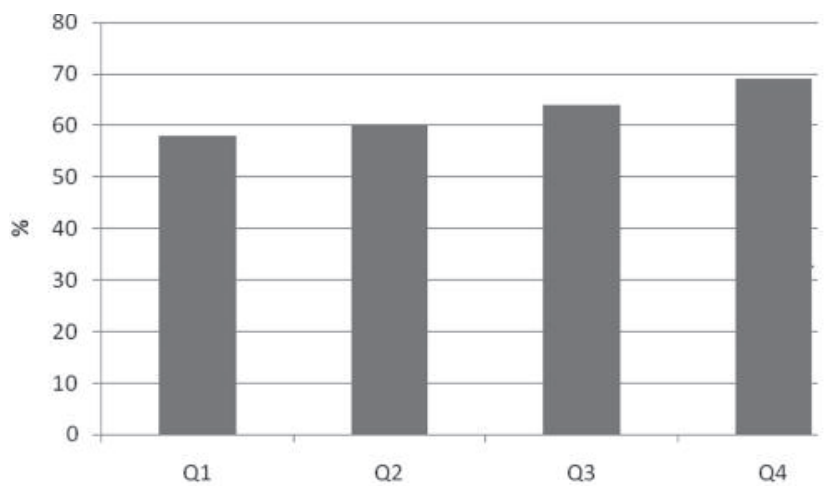

Figure 10. Proportion of individual's room nights booked through Hotel's website to the total room nights of individuals.

(Source: Aquaticum Hotel database)

This chart shows that the proportion of room nights booked through the Hotel's website by individual guests has a growing tendency.

\section{References}

P. Brewer -S. Marek (2006): Revenue Management. American Hotel and Lodging Educational Foundation, Washington DC, pp.7-14

Hotel Association of Hungary (HAH) (2010): A hazai szállodaipar jelenlegi helyzetének értékelése (Valuation of Status of the Hungarian Hotel Industry), www.hah.hu

M.G. Jagels - C.E. Ralston (2007): Hospitality Management Accounting, John Wiley \& Sons, Inc, Hoboken, New Jersey, pp. 278-280, ISBN-13: 978-0-471-68789-4

S.E. Kimes (2001): Yield Management Report, Center for Hospitality Research at Cornell University, pp. 2-6

S.E. Kimes (2010): Pricing Strategy and Distribution Channels in Hotel Revenue Management, Cornell University, Distance learning online material, Ithaca, New York

Y. Sedat (2007): An Integrated Forecasting Approach to Hotel Demand. Mathematical and Computer Modeling, Volume 46, Issues 7-8, October 2007, pp.1063-1070

C. de Seve (2008): Room Taxes and Economic Impact of the Lodging Industry. American Hotel and Lodging Educational Foundation, Washington DC, pp. 23-24

Aquaticum Debrecen, www.aquaticum.hu

Központi Statisztikai Hivatal (Hungarian Central Statistical Office), www.ksh.hu 